\title{
THE PERSISTENCE SPATIAL SETTLEMENTS BALUWARTI SURAKARTA SINCE 1749-2018
}

\author{
Tri Hartanto ${ }^{1,3 *}$, Tony Atyanto Dharoko ${ }^{1}$ and Yoyok Wahyu Subroto ${ }^{2}$ \\ ${ }^{1.2}$ Department of Planning and Architecture Engineering, Engineering Faculty, UGM Yogyakarta \\ Grafika Street No.2 UGM Campus, Yogyakarta 55281 Phone 0274542973 \\ ${ }^{3}$ Department of Architecture, Engineering Faculty, Tunas Pembangunan University of Surakarta \\ Walanda Maramis Street No.31 Cengklik Surakarta 57135 Phone 0271853824 \\ *Corresponding author; Email: tri.hartanto23@yahoo.com
}

\begin{abstract}
The background of Baluwarti settlement establishment derived from formal bond between people (kawula) and the court. This formal bond can be status of abdi dalem (giving service to the king/court) with title or kekancingan from the King. Dwelling was classified by status, role, and grade of respective dwellers. Thus, Baluwarti settlement is believed to have typical spatial layout because it was constructed with the Court's traditional and cultural value concepts remaining to be visible today. Based on qualitative research paradigm and historical reading method, this research could see that the spatial layout of Baluwarti Settlement is circling or going around kedhaton concentrically. Single orientation faces to kedhaton. This form has a spatial function as defense and security system, serving or subjugating system, and tradition preserving system. Overall, the original form of Baluwarti Settlement's spatial layout is still maintained until today, for about 270 years.
\end{abstract}

Keywords: Resilience; spatial layout; Baluwarti settlement.

\section{INTRODUCTION}

In 1742 King Paku Buwana II moved Kartasura Kingdom that had been devastated due to war to Solo hamlet. Then, after the Court's main building had been constructed completely in 1745 the king Paku Buwana II announced a new name for his kingdom, Surakarta Hadiningrat. Reigning not too long, in 1749 King Paku Buwana III passed away and succeeded by King Paku Buwana III. During Paku Buwana III's reign, Baluwarti Settlement started to be constructed, located in Baluwarti area. Baluwarti area is the one in the second circle after the main area of court (kedhaton), surrounded by a sturdy and high fortress called Baluwarti Fortress. Thus, Baluwarti settlement belonged to the kingdom city area (kingdom capital) at that time.

Settlement pattern in Baluwarti Settlement neighborhood can be seen from area division, or dwelling area according to upper-lower social groups. Bourgeoisies and high officials of the court resided in the location located in the edge of main ring road, while abdi dalem occupied their dwelling in inner circle of settlement. KGPH Poeger (2016) suggested that the area from which Baluwarti Settlement was constructed is the court-owned intended to be residences for sentana dalem and abdi dalem, with the status of using right (magersari). In line with KGPH Poeger, according to Kanjeng Budaya (2016), this land was intended to be residences for sentana dalem and abdi dalem to enable them including pangeran (princes), regents, soldier, dancer, penabuh (the one striking drum) and other abdi (servants), to face the King immediately when necessary.
The elements of settlement such as settlement's spatial layout pattern (physical aspect), and its community's social-cultural life tradition along with any rites (non-physical aspect) are still implemented by some people in Baluwarti Settlement until today, bringing about distinctive typicality. It is this typicality that makes Baluwarti Settlement neighborhood located inside the Court different from other settlements (outside the Court) in Surakarta.

Baluwarti Settlement originally constructed to be kingdom city area was of course designed as well as possible by King Paku Buwana III beginning the construction at that time. Considering the field exploration, it can be found that spatial layout of Baluwarti settlement is composed of physical and non-physical elements still visible until today. Thus, the research question of statement in this research is what does the form of Baluwarti Settlement's spatial layout designed by Paku Buwana III look like, and how much is the effectiveness of spatial layout still maintained until today?

The objectives of research are to see and to find out the extent to which shape and function of spatial layout designed by King Paku Buwana III is still maintained by Baluwarti people until today.

\section{METHOD}

This research paradigm was qualitative research, while the research method employed was inductive qualitative one with historical reading. Historical reading was used to find out the original form of Baluwarti Settlement's spatial layout constructed, through books or babad telling about the condition at 
that time, document/archive/magazine/article, and picture in that period and seeing the artifact still existing. The elements of Baluwarti Settlement's spatial layout still maintained until today were also used. Furthermore, inductive qualitative approach with in-depth interview was used to reveal the factors leading the people to hold tightly on traditional and cultural values so that Baluwarti Settlement's spatial layout constructed during Paku Buwana II time is still maintained.



Fig. 1. Research Method

Meanwhile, techniques of collecting data used were field observation, field documentation, and indepth interview. Having obtained data and information from historical source, the author would make the reconstruction of Baluwarti Settlement' spatial structure, thereby giving a description about the original condition of this settlement, and the elements of spatial structure based on the Court's tradition and culture (Javanese Culture) as the composer of its spatial structure. It is this condition that will underlie the assessment on the existence of spatial layout concept of Baluwarti Settlement.

\section{THEORETICAL STUDY}

A variety of building shapes as architectural work is adjusted with its function. Similarly, the form or shape of Court building is of course adjusted with its function. The term of kraton (English: Court or Palace) has some definitions, according to Soeratman (2000:79): firstly, it is defined as state (Javanese: nagari) or kingdom. Secondly, it is defined as the King's yard including the area inside cempuri (wall surrounding the yard). Thirdly, it is the residence of king (ratu) along with his family or the center of government having autonomous government. Then, physical characteristics of kraton, according to Soeratman (2000:79), are: a) having alun-alun (square), b) having unique building, c) having specialty, d) having widest size, e) its government is the king's monopoly. A kingdom generally has some regions as its domination area and all of kingdom areas are concentrated on the kingdom capital. During Mataram Islam period, regionally the regions supporting Javanese culture existing were called negari gung (palace or court area) and coastal area. Javanese culture living in Yogyakarta and Surakarta called negari gung is Javanese people civilization originating from the court. Meanwhile the one called coastal culture can be seen in the cities located in the North Beach of Java Island including IndramayuCirebon in the west and Gresik in the east.

Rapoport (1989) suggested that spatial layout is a physical environment in which there is an organizational relationship between various objects and human beings separated in certain spaces. Then, spatial layout pattern of settlement contains three elements: space with its composing elements (building and space surrounding) and formation meaning composition and pattern or model of a composition (Wikantiyoso in Krisna, 2005:17). Meanwhile, spatial structure is represented through identifying place, track, and border as main components, to be oriented furthermore through hierarchy and network or track likely arising in built environment either physically or nonphysically (Norberg-Schulz, 1979:21-28). Javanese traditional architecture is in separable from symbolization containing the message to be delivered beyond its architectural physical form. The role of symbol in Javanese traditional architecture is always related to its functional and esthetical purposes. It means that the form of Javanese traditional architecture is highly affected by the objective to be achieved in the term of utility (as residence) and non-functional purpose, i.e. prestige, indicating social strata status and etc (Sulistyono, 2002:25).

Levi-Strauss (1963:121) conducting many cultural studies found that community has complex (social) structure based on dualism form in the simplest relation order. This relation is called binary opposition, so that Levi-Strauss (1963:133-135) indicated that there is dualism pattern in every community culture. Furthermore, this community's social structure in fact arises in the establishment of settlement space that can be described simply in binary position, generally representing the position of men-women, child-adult, top-down, center-periphery, and etc (Levi-Strauss, 1963:141-143).

\section{RESULT AND DISCUSSION}

\section{Baluwarti Settlement during Paku Buwana III's Reign.}

The development of Kasunanan Surakarta palace, including Baluwarti Settlement, is explained in Pustaka Radya Laksana book. The book using Javanese letter explains descriptively the development or the construction of court area from Paku Buwana II 
to Paku Buwana XII reigns. During Paku Buwana III's reign, the King had established the border of court's main area (the court area) by constructing high and sturdy Baluwarti fortress. Then, to support the security, the access to that area was limited, entrance access was through Kori Brajanala Utara, while the exit was through Kori Brajanala Selatan, completed with Bangsal Wisamarta and Bangsal Brajanala (Wisamarta and Brajanala Wards) where the soldiers stood guard. Then, other buildings constructed were: buildings in Mosque (Masjid) complex, buildings in Kadipaten complex, buildings in Siti Hinggil Utara complex, Siti Hinggil Selatan, Pendapa Ageng Sasanasewaka, Kori Sri Manganti, and renovating Pagar Bumi (Baluwarti fortress) formerly made of bamboo into the one made of brick (pager banon). The development in Baluwarti settlement area included repairing fortress wall, houses for soldiers in Tamtaman, Carangan, and Wirengan. In addition, the king also constructed Kestalan (the stalls of horses pulling the carts of the King's daughters and Langensari (Horse park for soldiers), located in the south of Alunalun Selatan (South Square). However the existence of Kestalan and Langensari artifacts could not be found. Figure 2 shows the reconstruction of Baluwarti Settlement during King Paku Buwana III's reign, based on data of Pustaka Radya Laksana (Hardiyanti, 2004) and field observation.

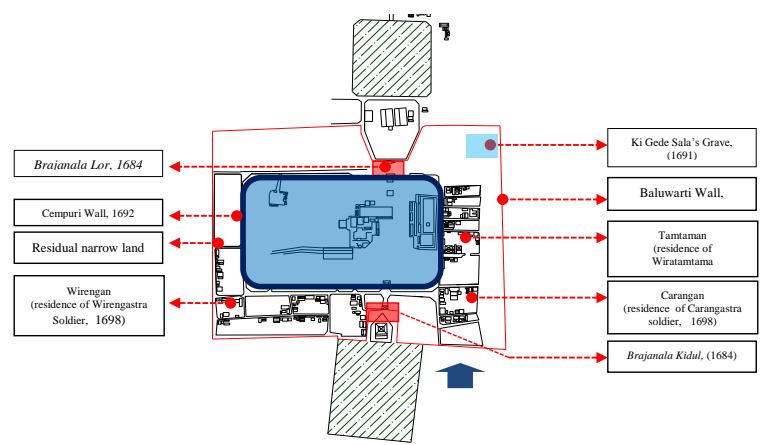

Fig. 2. Condition of Baluwarti Settlement during Paku Paku Buwana III time (1749-1788AD) (Source: Pustaka Radya Laksana, Hardiyanti, 2004, and Analysis, 2017)

\section{Spatial Layout Concept of Baluwarti Settlement}

Based on the research publication of Hartanto (2018: 303-395) which was carried out previously it was known, that the concept of Baluwarti settlement spatial structure has three main functions: a) spatial layout system as defense and security, b) spatial layout as service to the king, and c) spatial layout as a means of preserving tradition and culture.

\section{Spatial layout system as defense and security}

Spatial layout of Baluwarti settlement established as defense system is manifested into physical elements such as: a) Baluwarti fortress, the existence of which goes around the area with thickness and height that can ensure the security and defense against the enemy, b) kori Brajanala is limited entrance and exit access that is always safeguarded by soldiers, and this gate is always closed at night, c) dwelling pattern has grid pattern shape, creating a life defense space of kawula/abdi dalem residing in this area, d) dwelling pattern shape going around (circling) the kedhaton concentrically also creates defense space. Meanwhile non-physical elements composing defense system include a) belief in the King's infinite power/rule. The presence of belief within community that a king has ability far above that of ordinary human, giving the people/kawula the feeling of secure, b) the giving of title to kawula with certain status will grow the sense of being responsible for the security of Baluwarti environment/areas.

\section{Spatial Layout as giving service to the King}

Spatial layout of Baluwarti Settlement is created as a system of serving or giving service to the King as manifested into physical elements: a) road network, created to go around and to be oriented to kedhaton/ palace/king, so that the coverage in fulfilling the king/palace's need becomes closer, quicker and easier, b) in-group dwelling pattern with grid pattern road network facilitates the chairperson/leader to coordinate his subordinates, c) abdi dalem dwelling pattern classified by their expertise also facilitates and accelerates coordination, d) settlement site/area going around kedhaton/king facilitates the service from any corners. Meanwhile, non-physical elements of spatial layout contributing to creating the system of catering to (serving) the king are: a) magersari system, in which this system governs the duty and obligation of kawula becoming abdi dalem, in which kawula serving the King get residence until his descendants, b) economic system occurring during PB III's reign was subsystem economy, in which people produce material and tool according to the king and family's needs.

\section{Spatial layout system as the means of preserving tradition and culture}

Spatial layout of Baluwarti settlement is established to be a system to preserve tradition and culture as manifested into physical elements: a) the form of Javanese traditional-style residence buildings for abdi dalem, sentana dalem and dalem pangeran, applying the form of residences according to its dwellers. Dwellers with highest stratum occupy Joglo-shaped house, while abdi dalem occupies limasan/kampongshape house, b) people living inside Baluwarti fortress 
have obligation different from that of people living outside, in which the people inside have regulation defined by the king/the court, c) the existence of $\mathrm{Ki}$ Gede Sala's grave in Baluwarti environment is the manifestation of respect to his merit for giving all of his area to Surakarta Palace to construct the court.

Meanwhile, non-physical elements of spatial layout embodying the tradition and culture preserving system are: a) microcosmic belief, Hindu and Islam religion tenets teaching human beings to keep maintaining the relationship between fellow human beings and with Almighty God, b) norms held on in living within society originating from the court's norms that are applied according to the condition, c) court tradition and culture, in which Baluwarti people are the actor who implements the court's tradition and rite, according to the King's instruction. In addition, people also participate in organizing the rite imitating what the court has implemented according to condition.

\section{Indicator Formulation}

To find out the survival of spatial layout elements from Paku Buwana III to Paku Buwana XIII's reign (today), a formulation of indicator is required to see the survival of elements maintained in mezzoscale, particularly tangible element. Meanwhile the non-physical (intangible) elements of spatial layout are analyzed based on the result of data and information exploration from informants. Considering library study and indications/ phenomena found from the result of grand tour and mini tour (more in-depth field observation), the indicators that can be used to see the survival of settlement's spatial layout elements in mezzo-scale can be seen, as described in the analytical chart depicted in Figure 3.

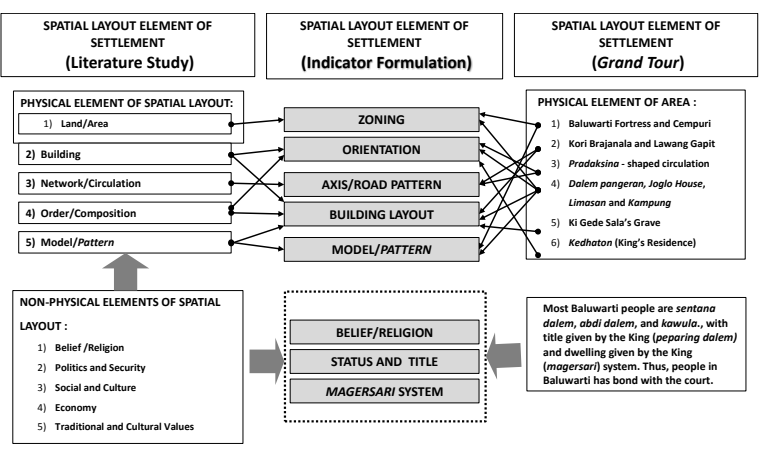

Fig. 3. The Formulation of Indicators as an Instrument of Seeing the Survival of Baluwarti Settlement's Spatial Layout

Considering the analysis on indicator formulation to see the survival of spatial layout elements of Baluwarti settlement during PB III to PB XIII reigns above, it can be found that the spatial layout elements that are still maintained by Baluwarti people can be seen through the following instrument.

a. Zoning, to see the persistence of area division by court's traditional and cultural values

b. Orientation, to see the survival of area orientation

c. Axis/road pattern, to see the survival of circulation network

d. Building layout, to see the survival of location/ position of putra dalem, sentana, and abdi dalem's dwelling.

e. Model/pattern, to see the composition form of dwelling

f. Belief/religion, to see whether or not it is held on tightly in Baluwarti community life.

g. Status and title, to see whether or not it is still used and supports the service to the King.

h. Magersari system, to see whether or not it still becomes a bond between abdi dalem and the king.

The Persistence of Settlement's Spatial Layout during Paku Buwana III - Paku Buwana V's reigns

The persistence of Baluwarti settlement's spatial layout can be seen based on the elements of Paku Buwana III's spatial layout that is still maintained through Paku Buwana V can be seen in Figure 4.

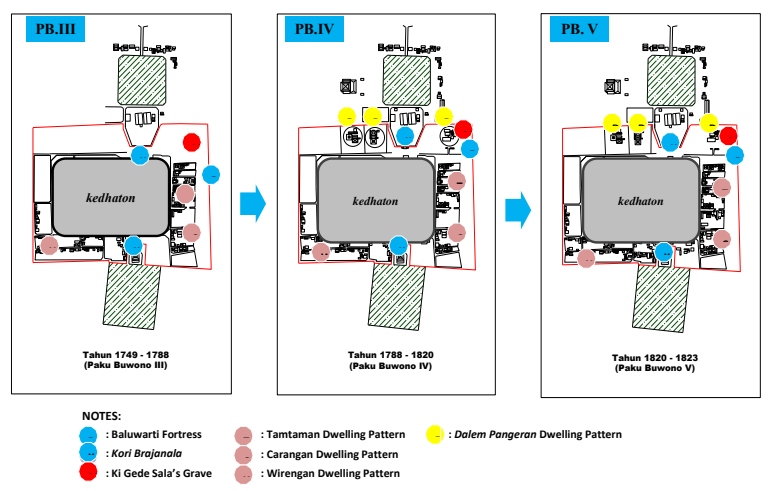

Fig. 4. The Persistence of Settlement's Spatial Layout during PB III-PB.V Reigns (Source: Pustaka Radya Laksana; Hardiyanti, 2004; and Analysis, 2017)

The existence of Baluwarti fortress and soldier abdi dalem dwelling groups going around kedhaton (king) serves to be defense and security system effectively. Circulation system with road network is oriented to the King functions as serving system effectively. Then, the existence of dalem pangeran houses contributes to maintaining tradition and culture. It indicates that the spatial layout of settlement going around the king (kedhaton) concentrically supported by circulation system supports the function of planned spatial layout concept very effectively. 
Considering the reconstruction of Baluwarti settlement, it can be seen that the spatial layout of Paku Buwana V period continues and maintains the spatial layout element in Paku Buwana III's reign. The elements of spatial layout are:

a. Dalem pangeran dwelling group is located in front of and around the main road, while abdi dalem is located beside and behind it, thereby clarifying the zoning of area.

b. Dwelling group and road network are oriented to the King

c. Building layout is adjusted according to status and profession, starting from the one closest to the king, putra dalem, sentana, and abdi dalem

d. Model/pattern of dwelling creates group and goes around the kedhaton (the king's position).

The Persistence of Settlement's Spatial Layout during Paku Buwana VI - Paku Buwana VIII's reign

The persistence of Baluwarti settlement's spatial layout can be viewed from the spatial layout elements in Paku Buwana VI period still maintained through Paku Buwana VIII period, as depicted in Figure 5.

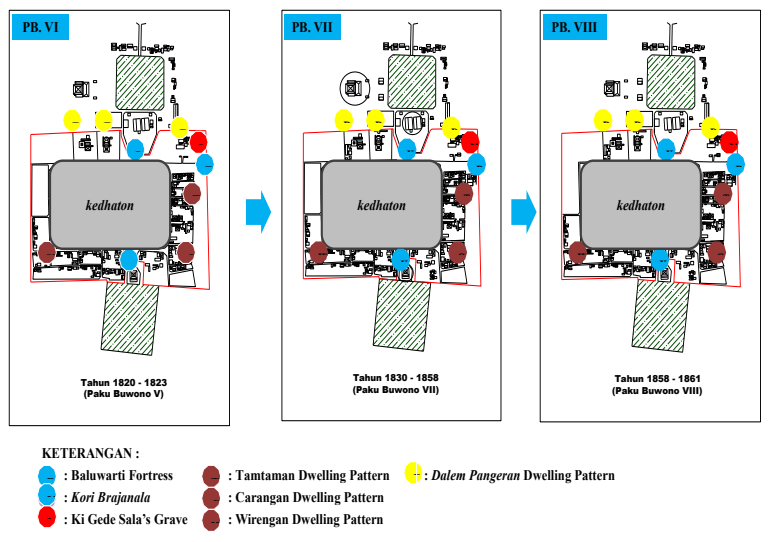

Fig. 5. The Persistence of Settlement's Spatial Layout during PB.VI - PB.VII's Reign (Source: Pustaka Radya Laksana; Hardiyanti, 2004; and Analysis, 2017)

The existence of Baluwarti fortress and abdi dalem, sentana dalem, and dalem pangeran dwelling groups going around kedhaton (king) serving as defense and security effectively. Circulation system with road network oriented to the King functioning as serving system effectively. Then, the existence of dalem pangeran and abdi dalem houses contributing to the organization of court's tradition is an effective means of maintaining tradition and culture. Because the elements of spatial layout existing can realize function and concept of spatial layout planned, this spatial layout form is still maintained.
Considering the reconstruction of Baluwarti settlement, it can be seen that spatial layout of Paku Buwana VI's time is continued and maintained in Paku Buwana VII's, and then spatial layout of Baluwarti settlement during Paku Buwana VIII period continues and maintains the spatial layout elements existing in Paku Buwana VI and Paku Buwana VII periods. The elements of spatial layout are:

a. Dalem pangeran dwelling group is in front of and around the main road, while abdi dalem is located beside and behind it, thereby clarifying the zoning of area.

b. Dwelling group and road network are oriented to the King

c. Road axis/pattern stretches from the North to the South

d. Building layout is adjusted according to status and profession, starting from the one closest to the king, putra dalem, sentana, and abdi dalem

e. Model/pattern of dwelling creates group and goes around the kedhaton (the king's position).

\section{The Persistence of Settlement's Spatial Layout during Paku Buwana IX - Paku Buwana XI periods}

The persistence of Baluwarti settlement's spatial layout can be seen based on the elements of spatial layout in Paku Buwana IX time is still maintained through Paku Buwana XI time, as depicted in Figure 6. The existence of Baluwarti fortress and abdi dalem, sentana dalem, and dalem pangeran dwelling group going around kedhaton (king) serving as defense and security very effectively. Similarly, the expansion in the West part of area makes the function of Baluwarti settlement as defense and security system stronger. The increase of abdi dalem dwellings with new profession and circulation system with road network oriented to the king functions as serving system effectively. The addition of lawang gapit opens the room of interaction between Baluwarti and people surrounding. Then, the existence of dalem pangeran and abdi dalem houses contributes to the organization of court's traditional rite is an effective way of maintaining tradition and culture.

Considering the reconstruction of Baluwarti settlement, it can be seen that spatial layout in Paku Buwana IX's time is still continued and maintained in Paku Buwana X, and then the spatial layout of Baluwarti settlement in Paku Buwana XI continues and maintains the elements of spatial layout existing in Paku Buwana IX and Paku Buwana X. Those elements of spatial layout are: 
a. Dalem pangeran dwelling group is in front of and around the main road, while abdi dalem is located beside and behind it, thereby clarifying the zoning of area.

b. Dwelling group and road network are oriented to the King

c. Road axis/pattern stretches from the North to the South

d. Building layout is adjusted according to status and profession, starting from the one closest to the king, putra dalem, sentana, and abdi dalem

e. Model/pattern of dwelling creates group and goes around the kedhaton (the king's position)

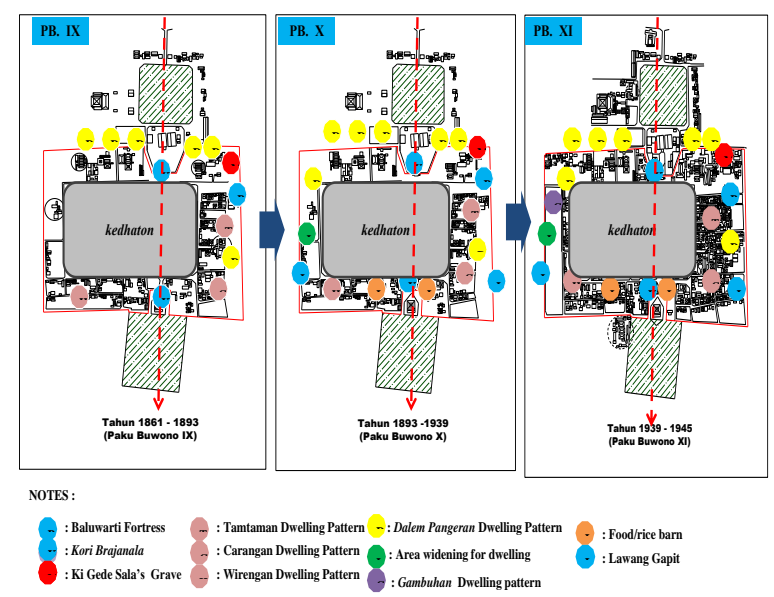

Fig. 6. The Persistence of Settlement's Spatial Layout in PB.IX - PB.XI period (Source: Pustaka Radya Laksana; Hardiyanti, 2004; and Analysis, 2017)

\section{The Persistence of Settlement's Spatial Layout during Paku Buwana XII - Paku Buwana XIII periods}

The persistence of Baluwarti settlement's spatial layout can be seen based on the elements of spatial layout in Paku Buwana XII time is still maintained through Paku Buwana XIII time, as depicted in Figure 7. The existence of Baluwarti fortress and abdi dalem, sentana dalem, and dalem pangeran dwelling group going around kedhaton (king) serving as defense and security very effectively. Similarly, the expansion in the West part of area makes the function of Baluwarti settlement as defense and security system stronger. The increase of abdi dalem dwellings with new profession and circulation system with road network oriented to the king functions as serving system effectively. The addition of lawang gapit opens the room of interaction between Baluwarti and people surrounding. Then, the existence of dalem pangeran and abdi dalem houses contributes to the organization of court's traditional rite is an effective way of maintaining tradition and culture.

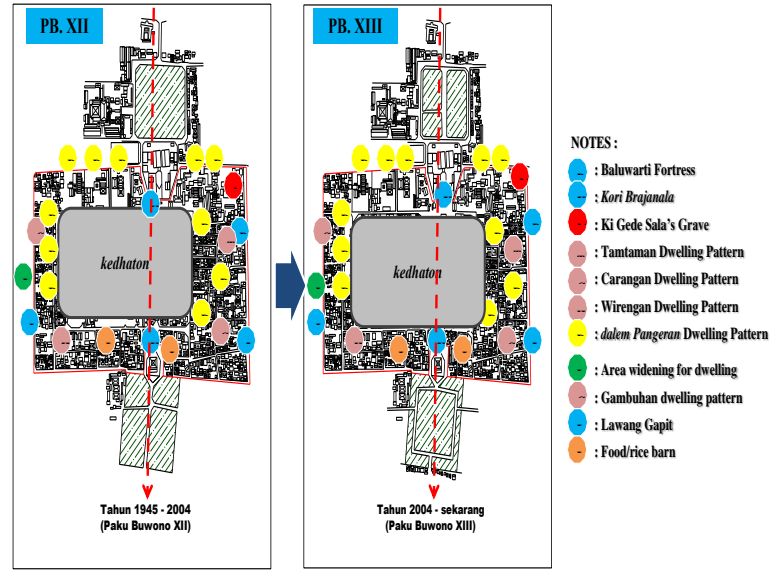

Fig. 7. The Persistence of Settlement's Spatial Layout in PB.XII - PB.XIII period (Source: Pustaka Radya Laksana; Hardiyanti, 2004; and Analysis, 2017)

Considering the reconstruction of Baluwarti settlement, it can be seen that spatial layout in Paku Buwana XII time is still continued and maintained in Paku Buwana XIII. Those elements of spatial layout are:

a. Dalem pangeran dwelling group is in front of and around the main road, while abdi dalem is located beside and behind it, thereby clarifying the zoning of area.

b. Dwelling group and road network are oriented to the King

c. Road axis/pattern stretches from the North to the South

d. Building layout is adjusted according to status and profession, starting from the one closest to the king, putra dalem, sentana, and abdi dalem

e. Model/pattern of dwelling creates group and goes around the kedhaton (the king's position)

The survival of physical form of Baluwarti Settlement's spatial layout in the period of Paku Buwana II until today (Paku Buwana XIII) can be seen from zoning, orientation, road axis/pattern, building layout, and model/pattern. Meanwhile, nonphysical elements of spatial layout still maintained until today are belief/religion, status and degree, and magersari system. Table 1 explains the relationship between spatial layout elements supporting the function of spatial layout that can run effectively, so that the shape of spatial layout remains to be maintained until today.

\section{Factors Affecting Communities Maintaining the Specificity of Spatial Settlements}

Factors Affecting Communities Maintaining the Specificity of Spatial Settlements Based on in-depth 
interviews with several speakers, namely Baluwarti residents who have lived in the Baluwarti settlement for a long time, information is obtained regarding matters that encourage residents to maintain the spatial layout of the settlements to this day, while still believing and carrying out existing traditions and culture. The information that the researchers obtained, was then grouped into three main factors, namely: (a) the desire of citizens to preserve traditions and cultures that have been handed down for generations by their ancestors, (b) the outward and inner sense of security, and (c) the desire keep serving (ngalap blessings) to the king/palace. The non-physical elements of spatial planning (trust/religion, magersari system, and status and degree) are also factors that encourage the community to maintain the peculiarities of residential spatial planning. Where trust / religion is the basis of society to preserve the traditions and culture of the palace by believing in the values and meanings contained in it. While the magersari system is an emotional bond that exists between court servants and kings, so that both parties will mutually member and accept, and maintain in terms of security. The status and title also become a strong bond, so that the servants/servants of the palace still trust the king / palace that can give blessings to life.

\section{CONCLUSION}

\section{Conclusion}

The defense of the Baluwarti settlement spatial structure which was built early in the reign of the king of Paku Buwana III (1749-1788), until now has passed a long period of more than 250 years. Defense is caused by spatial forms in accordance with functions. Spatial structure is formed by physical elements of spatial planning, among others: zoning (concentric patterns), orientation (single orientation), axis/road pattern (North-South/pradaksina), building layout (status and profession), and model/pattern (grid pattern). While the non-physical elements that contribute to defense to date are: belief/religion, status and title, and the magersari system. As for the factors that influence the community today still maintain settlement spatial planning, namely: (a) the desire of citizens to preserve traditions and cultures that have been handed down for generations by their ancestors, (b) creating a sense of security outwardly and inwardly, and c) the desire to keep serving (ngalap berkah) to the king / palace.

Although functionally the spatial layout has been adjusted with the present condition, generally the

Table 1. Spatial Layout Elements of Baluwarti Settlement Still Maintained from PB III to PB XIII Periods

\begin{tabular}{|c|c|c|c|}
\hline \multirow{2}{*}{$\begin{array}{l}\text { EXISTENCE OF } \\
\text { SPATIAL } \\
\text { LAYOUT } \\
\text { ELEMENTS }\end{array}$} & \multicolumn{3}{|c|}{ SPATIAL LAYOUT ELEMENTS STILL MAINTAINED AFTER PB. III PERIOD - TODAY } \\
\hline & AS A SECURITY SYSTEM & AS A SYSTEM TO SERVE THE KING & AS A TRADITION PRESERVING SYSTEM \\
\hline $\begin{array}{l}\text { ZONING } \\
\text { (concentric } \\
\text { pattern) }\end{array}$ & $\begin{array}{l}\text { Putra dalem, sentana, abdidalem, dan } \\
\text { kawula/people residence area, was designed } \\
\text { concentrically going around the King and } \\
\text { surrounded by high and sturdy Baluwarti Fortress. }\end{array}$ & $\begin{array}{l}\text { The Court's officials with large responsibility } \\
\text { and obligation occupy the residence close to } \\
\text { the King (in front of, on the right and the left } \\
\text { of Kedhaton). }\end{array}$ & $\begin{array}{l}\text { Area close to the King is considered as highly } \\
\text { sacred. Thus, the position of dalem pangeran is } \\
\text { close to the king, while that of abdidalem is } \\
\text { slightly far. }\end{array}$ \\
\hline $\begin{array}{l}\text { ORIENTATION } \\
\text { (single orientation) }\end{array}$ & $\begin{array}{l}\text { Court (king) is the center of cosmos thereby is } \\
\text { believed as having magic power, and capable of } \\
\text { giving safety and security }\end{array}$ & $\begin{array}{l}\text { King is the manifestation of God, thereby } \\
\text { people/kawula keep respecting him. }\end{array}$ & $\begin{array}{l}\text { King is believed as having advantages, because } \\
\text { the king is considered as God's manifestation. } \\
\text { The court is the source of Javanese culture and } \\
\text { tradition. }\end{array}$ \\
\hline $\begin{array}{l}\text { ROAD } \\
\text { AXIS/PATTERN } \\
\text { (north-south/ } \\
\text { pradaksina) }\end{array}$ & $\begin{array}{l}\text { Kori Brajanala Utara and Selatan as the axis of } \\
\text { area is always safeguarded by abdi dalem/court's } \\
\text { soldier }\end{array}$ & $\begin{array}{l}\text { Pradaksina main road circulation means } \\
\text { nengenaken raja (transcending the King) }\end{array}$ & $\begin{array}{l}\text { Kori Brajanala Utara and Selatan as the axis of } \\
\text { area is defined as which one or where the } \\
\text { human life destination are (sangkan paraning } \\
\text { dumadi). }\end{array}$ \\
\hline $\begin{array}{l}\text { BUILDING LAYOUT } \\
\text { (status and } \\
\text { profession) }\end{array}$ & $\begin{array}{l}\text { The area is surrounded with high and sturdy } \\
\text { Baluwarti Fortress. } \\
\text { The dwelling pattern is Grid pattern and goes } \\
\text { around kedhaton (king). }\end{array}$ & $\begin{array}{l}\text { Officials and putra dalem reside closely to } \\
\text { the King, while abdi dalem dwelling is } \\
\text { located beside and behind kedhaton (king). }\end{array}$ & $\begin{array}{l}\text { Baluwarti Fortress is a border of Baluwarti area, } \\
\text { in which this settlement is intended to putra } \\
\text { dalem, sentana, and abdidalem. }\end{array}$ \\
\hline $\begin{array}{l}\text { MODEL/PATTERN } \\
\text { (grid pattern) }\end{array}$ & $\begin{array}{l}\text { Abdidalem dwelling pattern has grid pattern, and } \\
\text { other dwelling creates groups going around the } \\
\text { king. }\end{array}$ & $\begin{array}{l}\text { Dwelling grouping facilitates the } \\
\text { coordination of the King's instruction } \\
\text { implementation. }\end{array}$ & $\begin{array}{l}\text { The shape of dwelling and settlement pattern is } \\
\text { classified by its status and role to the king. }\end{array}$ \\
\hline $\begin{array}{l}\text { BELIEF/RELIGION } \\
\text { (still existing) }\end{array}$ & $\begin{array}{l}\text { Life safety can be achieved by maintaining the } \\
\text { harmonious relationship between God, fellow } \\
\text { human beings, and nature (physical and } \\
\text { metaphysical/invisible natures) }\end{array}$ & $\begin{array}{l}\text { The King also has title kalifatullah } \\
\text { panatagama, so that people/ kawula have } \\
\text { an obligation to serve the leader / King. }\end{array}$ & $\begin{array}{l}\text { The king is trusted and respected by } \\
\text { people/kawula, in addition to be government } \\
\text { leader and Javanese custom, tradition and } \\
\text { culture guard. }\end{array}$ \\
\hline $\begin{array}{l}\text { STATUS AND TIITLE } \\
\text { (still existing) }\end{array}$ & $\begin{array}{l}\text { Status and title owned by putra dalem, sentana, } \\
\text { and abdidalem has a consequence to be } \\
\text { responsible for the court's security. }\end{array}$ & $\begin{array}{l}\text { Status and title owned by putra dalem, } \\
\text { sentana, and abdidalem have consequence } \\
\text { to serve the king. }\end{array}$ & $\begin{array}{l}\text { Title and status indicate an individual's role, } \\
\text { status, and position. Title and status are } \\
\text { obtained based on the effort made }\end{array}$ \\
\hline $\begin{array}{l}\text { MAGERSARI } \\
\text { System (still } \\
\text { existing) }\end{array}$ & $\begin{array}{l}\text { Putra dalem, sentana, and abdidalem got right to } \\
\text { land and building from the court. Thus, they have } \\
\text { an obligation to safeguard the court. }\end{array}$ & $\begin{array}{l}\text { Putra dalem, sentana, and abdidalem are } \\
\text { the pillars also responsible for the existence } \\
\text { of court. }\end{array}$ & $\begin{array}{l}\text { Magersari system is the implementation of the } \\
\text { king's agung binathara characteristic, the } \\
\text { obligation of protecting all of its } \\
\text { kawula/people. }\end{array}$ \\
\hline
\end{tabular}


three functions of Baluwarti settlement's spatial layout planned by Paku Buwana III including: 1) spatial layout system as defense and security, 2) spatial layout as service to the king, and 3) spatial layout as a means of preserving tradition and culture are still considered as effective until today. It is indicated with Baluwarti Settlement's area still revealing its original shape such as dwelling groups going around kedhaton (king), circulation pattern and road network oriented to kedhaton (king), grid pattern-shaped dwelling, and layout adjusted with status and title. Additionally, most Baluwarti people still maintain tradition and culture originating from the Court now.

\section{Acknowledgment}

This paper is a part of the author's dissertation, in Universitas Gadjah Mada (Gadjah Mada University) of Yogyakarta. For that reason, the author would like to express his gratitude to all of those supporting this study. He also would like to say thank to the informants for information, data, and time devoted to this study. The author also expresses his big thank to promoter and co-promoters.

\section{GLOSSARY}

\begin{tabular}{|c|c|}
\hline Abdi Dalem & $\begin{array}{l}\text { retainers; courtiers; member of the } \\
\text { royal household }\end{array}$ \\
\hline Alun-Alun & : great field in front of a \\
\hline Karaton & : court; ruler's residence \\
\hline Beteng Baluwarti : & : inner wall surrounding the \\
\hline Karaton & : court; ruler's residence \\
\hline Dalem Pangeran & : aristocratic mansion \\
\hline Kedhaton & : inner court \\
\hline Kekancingan & : aristocratic rank; title \\
\hline Karaton & : court; ruler's residence \\
\hline Kawula & : followers; (the) people; citizens \\
\hline Kori & : gate \\
\hline Kori Brajanala Lor : & $\begin{array}{l}\text { name of the main gate leading to and } \\
\text { from the court's front yard }\end{array}$ \\
\hline Kori Brajanaka Kidul : & $\begin{array}{l}\text { : southern gate giving access to Siti- } \\
\text { hinggil Kidul }\end{array}$ \\
\hline Lawang & : gateway; door \\
\hline Lawang Gapit Wetan: & : Baluwarti's eastern entrance gate \\
\hline Lawa & : Baluwarti's western entrance gate \\
\hline$g a$ & d; countr \\
\hline
\end{tabular}

Negorogung : rural areas surrounding the capital

Pradaksina : to circumambulate clockwise

Prajurit Dalem : royal armed force

Probosuyoso : name of the central, inner path of Javanese building

Sentana dalem : relative and in-law of the ruler

\section{REFERENCES}

Achmad, S., \& Wintala (2016). Babad Giyanti: Palihan Nagari dan Perjanjian Salatiga, Araska, Yogyakarta.

Bakker, A. (1995). Kosmologi dan Ekologi. Kanisius Yogyakarta.

Budihardjo, E. (1997). Jati Diri Arsitektur Indonesia. Alumni, Bandung.

Creswell, J. (2014). Penelitian Kualitatif Dan Desain Riset. Pustaka Pelajar. Yogyakarta

Goulding, C. (1999). Grounded Theory: Some Reflections on Paradigm, Rocedures and Misconceptions. Working Paper Series June 1999. ISSN 1363-6839. University of Wolverhampton, UK.

Hardiyanti, N.S., et.al. (2005). Studi Perkembangan dan Pelestarian Kawasan Keraton Surakarta. Journal Dimensi Teknik Arsitektur, 33(1), 112124.

KRMH, Y. (1994). Karaton Surakarta Hadiningrat, Bangunan Budaya Jawa sebagai Tuntunan Hidup/Pembangunan Budi Pakarti Kejawen. Macrodata Solo.

R.Ng., P. et.al. (1939). Pustaka Radya Laksana, Budi Utama, Surakarta. Yayasan Sastra Lestari.

Rapoport, A. (1969). House, Form, and Culture, Prentice Hall Inc, London.

Soeratman, D. (1989). Kehidupan Dunia Keraton Surakarta 1830-1939, Taman Siswa, Yogyakarta.

Straus, A. \& Corbin, J. (2015). Dasar-dasar Penelitian Kualitatif: Tatalangkah Dan Teknik-teknik Teoritisasi Data, Pustaka Pelajar, Yogyakarta.

Subanar, G.B. (2010). Manunggaling Kawula-Gusti Dalam Transisi; Potret Dunia Jawa dari Yogyakarta. Dalam kumpulan essai "Sesudah Filsafat", Yogyakarta.

Yayasan Pawiyatan Kabudayan Karaton Surakarta. (2004). Karaton Surakarta, Buku Antar Bangsa, Jakarta, Indonesia. 